\title{
desenho infantil e produtos culturais: como aparecem as sereias?
}

\author{
giovana scareli ${ }^{1}$ \\ universidade federal de são joão del-rei, brasil \\ sabrina da silva gava ${ }^{2}$ \\ universidade federal de são joão del-rei, brasil
}

\section{resumo}

O presente trabalho busca examinar a relação existente entre alguns desenhos produzidos por crianças do terceiro e quarto ano do Ensino Fundamental, de uma escola pública de Aracaju/SE, algumas imagens (filmes, ilustrações, pinturas, pôsteres, desenhos para colorir entre outros) inspiradas nas Sereias e dois poemas épicos que falam sobre essas personagens míticas, a saber: a Odisseia, de Homero, e a Metamorfoses, de Ovídio. Nossas discussões incidem sobre as possíveis influências da mídia e da indústria cultural sobre a produção gráfica infantil e como as crianças vão construindo suas referências imagéticas com esses exemplos, vindos dos meios de comunicação. Trata-se, neste sentido, de evidenciar o modo como essas imagens afetam a concepção que as crianças têm das Sereias e a forma com que elas expressam essas personagens em seus desenhos, geralmente com cauda de peixe - forma imagética exaustivamente reproduzida pela mídia e que acabamos, também, por mostrar em sala de aula através de uma pintura, não cogitando a possibilidade delas terem asas e/ou pés. Além disso, debruçamos o olhar sobre alguns desenhos infantis cuja forma imagética das Sereias foi "copiada" de desenhos ditos "para colorir". Nesse caso, observamos que a cópia padronizou e empobreceu os desenhos das crianças, bloqueando a criatividade e estabelecendo entre elas uma forma "correta" de desenhar as Sereias. Partindo dessas observações e da ideia de que as imagens são atuantes na construção de conhecimentos e nas formas de compreender e ler do mundo, nos propusemos a investigar este universo imagético das Sereias para fazer um trabalho de pesquisa com as imagens, colocando-as em outro patamar que não é o da mera "ilustração". Na nossa concepção, é necessário conhecer as especificidades de cada linguagem na qual a imagem é veiculada a fim de despertarmos um olhar crítico, sobretudo, no que tange à educação visual das crianças.

palavras-chave: mito; produtos culturais; desenho infantil; educação visual.

\section{children drawing and cultural products: how do mermaids appears?}

abstract

The present work seeks to examine the relation between some drawings produced by children of the third and fourth year of Elementary School, of a public school in Aracaju / SE, some images (films, illustrations, paintings, posters, coloring drawings among others) inspired by the mermaids and two epic poems that talk about these mythical characters, namely: Homer's Odyssey, and Ovid's Metamorphoses. Our discussions focus on the possible influences of the media and the cultural industry on children's graphic production and on how children construct their imagery references with these mediadriven examples. In this sense, it is a question of highlighting how these images affect the

\footnotetext{
${ }^{1}$ E-mails: gscareli@yahoo.com.br

2 E-mail: sabrinasgava@hotmail.com
} 
children's conception of Mermaids and the way they express these characters in their drawings, usually with fish-shaped imagery comprehensively reproduced by the media, an image we also ended up showing in the classroom through a painting, not considering the possibility of memaids having wings and/or feet. In addition, we look at some children's drawings whose imagery of the Mermaids was "copied" from drawings " to color". In this case, we observed that the copy standardized and impoverished children's drawings, blocking creativity and establishing between them a "correct" way of drawing the Mermaids. From these observations and the idea that the images are active in the construction of knowledge and in the ways of understanding and reading of the world, we set out to investigate this imaginary universe of the Mermaids to do a research work with the images, placing them in another position which is not the mere "illustration". In our conception, it is necessary to know the specificities of each language in which the image is conveyed in order to awaken a critical eye, above all, regarding the visual education of children.

keywords: myth; cultural products; childish drawing; visual education.

\section{dibujo infantil y produtos culturales: ¿cómo aparecen las sirenas?}

resumen

El presente trabajo busca examinar la relación que existe entre algunos dibujos producidos por niños de la primaria, de una escuela pública de Aracaju/SE, algunas imágenes (películas, ilustraciones, pinturas, afiches, dibujos para colorear, entre otros) inspiradas en las Sirenas y dos épicos poemas que hablan sobre esos personajes míticos, a saber: la Odisea, de Homero, y la Metamorfosis, de Ovidio. Nuestras discusiones inciden sobre las posibles influencias de los medios y de la industria cultural hacía la producción gráfica infantil y cómo los niños construyen sus referencias imagéticas con estos ejemplos, provenientes de los medios de comunicación. Se trata, en este sentido, de hacer evidente el modo en que esas imágenes afectan la concepción que los niños tienen de las Sirenas y la forma con la que ellos expresan estos personajes en sus dibujos, generalmente con cola de pez - forma imagética exhaustivamente reproducida por los medios y que terminamos, también, por mostrar en el aula a través de pinturas, sin considerar la posibilidad de que tengan alas y/o pies. Además, vamos a enfocar la mirada hacía algunos dibujos infantiles cuya forma imagética de las Sirenas fue "copiada" de dibujos "para colorear". En este caso, observamos que la copia impuso un patrón y empobreció los dibujos de los niños, bloqueando la creatividad y estableciendo entre ellos una manera "correcta" de dibujar las Sirenas. A partir de estas observaciones y de la idea de que las imágenes actúan en la construcción del conocimiento y en las formas de comprender y de leer del mundo, nos proponemos investigar este universo imagético de las Sirenas para hacer un trabajo de investigación con imágenes, poniéndolas en otro nivel que no es el de la mera "ilustración". En nuestra concepción, hace falta conocer las especificidades de cada lenguaje en el que la imagen es transmitida con el fin de despertar en nosotros una mirada crítica, sobre todo en lo que se refiere a la educación visual de los niños.

palabras clave: mito; productos culturales; dibujo infantil; educación visual. 
desenho infantil e produtos culturais: como aparecem as sereias?

Nunca se fez tão presente o universo imagético em nossas vidas, tal como é na atualidade. São inúmeras as imagens que nos fazem companhia: outdoors, cartazes, revistas, livros, quadrinhos, filmes, propagandas, folders, jornais, fotografias etc. Por estarem tão presentes, acabam sendo banalizadas de tal forma, que já não pensamos o quanto estamos sendo educados por elas.

Percebendo um mercado altamente favorável para a produção de bens culturais para a infância e juventude, a indústria cultural tem produzido muito e se aproveitado deste mercado que se encontra em expansão. Veiculados pela mídia, estes bens culturais tornam-se cada vez mais atraentes dada a "sofisticação" de suas imagens e se essas são capazes de seduzir facilmente um adulto, as crianças tornam-se alvo ainda mais fácil deste tipo de indústria, porém, com um agravante: elas acabam sendo mais influenciáveis nesta relação de consumo.

Mas não são apenas as imagens da indústria cultural atual que povoam o imaginário infantil, outras imagens clássicas ainda fazem parte do universo das crianças, como é o caso das ilustrações de contos de fadas, fábulas, lendas e mitos, que aparecem de várias formas, na contação de histórias, em salas de aulas, peças de teatro, adaptações cinematográficas, desenhos animados ou ainda, mais recentemente, na versão de jogos eletrônicos.

A partir da exposição a essas várias formas de contato com os produtos culturais e suas imagens, as crianças acabam por elaborar diferentes visões de seu meio social e uma das maneiras de expressarem essas influências é por meio dos seus desenhos. Provocadas pelas imagens vistas ou sugeridas, no processo de selecionar, interpretar e expressar os elementos que mais lhe chamaram a atenção, as crianças muitas vezes reproduzem graficamente em seus desenhos, elementos de sua experiência, seus pensamentos, sentimentos, como veem o mundo em que estão inseridas e, algumas vezes, percebemos as influências da mídia nesses desenhos. 
Esse trabalho é um dos frutos de uma pesquisa que vem sendo feita há alguns anos a partir de desenhos produzidos por crianças de uma escola pública de Aracaju/SE. Firmou-se uma parceria entre a escola, a universidade e um grupo que era composto por duas pesquisadoras, três alunos de iniciação científica e uma aluna de mestrado ${ }^{3}$, que passaram a frequentar a escola uma vez por semana. Foram seis encontros com o primeiro e segundo ano do Ensino Fundamental e, depois, seis encontros com terceiro e quarto ano.

A metodologia de trabalho dos encontros foi inspirada no programa Filosofia para Crianças (FpC), criada pelo filósofo americano Matthew Lipman (1922-2010), e nas leituras que fizemos de Walter Omar Kohan, professor da Universidade do Estado do Rio de Janeiro (UERJ), também sobre o mesmo assunto. Tal programa busca estimular as crianças a pensarem por si mesmas, de maneira reflexiva, criativa e autônoma, para que possam se tornar pessoas ativas e conscientes dentro da sociedade. E para estimulá-las a pensar desse modo, nada mais atraente do que uma boa história.

$\mathrm{Na}$ perspectiva de FpC, usa-se a novela ou o conto filosófico que, segundo Lipman, se caracteriza por apresentar um modelo de comunidade de diálogo filosófico ou investigação filosófica que aborda os aspectos problemáticos da experiência. [...] Os alunos, a partir da própria subjetividade, tomam o texto literário como pre-texto para obterem uma forma de expressão particular, crítica e criativa. Por isso, é possível usar um texto literário para gerar uma reflexão filosófica. Uma história dá pre-texto para criar muitas outras; uma história escrita dá ensejo para que o leitor ponha sua própria história em jogo, se arrisque a romper limites; isto é, se permita a pronunciar sua própria palavra e transformar o sentido único em muitos e diversos (GARZA. In: KOHAN; LEAL, 2000, p. 117; grifo do autor).

Assim, seguindo a esteira deixada por Matthew Lipman e as sugestões de Walter Omar Kohan para implementar a filosofia com crianças na escola, estipulamos que os nossos encontros teriam quatro momentos distintos, o que dava mais ou menos uma hora de trabalho com cada turma. Primeiro havia uma conversa informal para descontrair e acolher os alunos (atividade prévia ao trabalho textual); depois havia o momento da leitura de uma história que, para os

\footnotetext{
${ }^{3}$ Pesquisadoras: Giovana Scareli e Rosana Aparecida Fernandes; alunos de Iniciação Científica: Flávia dos Santos Nascimento; Marilia Gabriele Melo dos Santos; George Emmanuel do Nascimento Araújo e a Mestranda Jessica Gonçalves de Andrade. A todos o nosso agradecimento pelo trabalho compartilhado que resulta nesse artigo.
} 
dois primeiros anos eram contos de fadas e para os outros dois foram fábulas e textos mitológicos (apresentação - leitura de um texto); o terceiro momento era de problematização e discussão sobre o texto lido, com o intuito de trabalhar algumas habilidades do pensamento e, por fim, como síntese, pedíamos que eles fizessem um desenho (atividade posterior à discussão), conforme os passos que estão no livro "Filosofia para crianças: na prática escolar" 4 .

Esses encontros foram gravados em áudio, feitas anotações das observações e por fim, recolhidos os desenhos. Esse material foi digitalizado e transcrito, e compôs o banco de dados do projeto. Nesse banco de dados também foi feito um "banco de imagens" referentes a cada uma das histórias trabalhadas. Essas imagens foram capturadas na internet e em livros e, posteriormente, salvas ou digitalizadas.

Esses procedimentos fazem parte dos dispositivos que lançamos mão para realizar essa pesquisa, de cunho qualitativo e inspirada, também, pelo método da cartografia. $O$ projeto foi desenhado inicialmente, mas foi se constituindo no seu fazer e, vez ou outra, precisávamos mudar a forma de trabalhar ou levar outras histórias, pois o feedback das crianças nos faziam repensar as nossas escolhas. Isso aconteceu com o terceiro e quarto ano, que no projeto original não contemplava histórias mitológicas, mas como havia dois alunos que se chamavam Ícaro e por vários alunos conhecerem um jogo eletrônico com vários personagens mitológicos, resolvemos modificar o projeto original, incluindo as histórias de Dédalo e Ícaro. Como nesse mito aparece o Minotauro, que é um ser mitológico, acabamos por apresentar às crianças outros seres da mitologia grega.

Para a cartografia, é muito importante a interação entre pesquisador e as demais pessoas de um território que está sendo habitado, pois há uma intervenção direta nesse território e haverá trocas entre todos os "habitantes". Nesse sentido, a pesquisa intervenção

\footnotetext{
${ }^{4}$ KOHAN; WAKSMAN, 1998, p. 93.
} 
[...] exige do cartógrafo um mergulho no plano da experiência, lá onde conhecer e fazer se tornam inseparáveis, impedindo qualquer pretensão à neutralidade ou mesmo suposição de um sujeito e de um objeto cognoscentes prévios à relação que os liga. [...] O método, assim, reverte seu sentido, dando primado ao caminho que vai sendo traçado sem determinações ou prescrições de antemão dadas. Restam sempre pistas metodológicas e a direção ético-política que avalia efeitos da experiência (do conhecer, do pesquisar, do clinicar etc.) para daí extrair os desvios necessários ao processo de criação (PASSOS; BARROS. In: PASSOS; KASTRUP; ESCÓSSIA, 2012, p. 30-31).

Inspirados por esse método, seguimos com a pesquisa, tendo como principais pistas "habitar um território" e "acompanhar processos". O que víamos, sentíamos, percebíamos na escola, que era nosso território, nos levava a buscar referências de imagens e textos teóricos sobre o desenho infantil, sobre as histórias contadas e, assim, de acordo com nossas percepções no campo, formamos um conjunto de referenciais teóricos que só pode ser entendido pelo princípio da multireferencialidade, já que são textos que abordam o desenho infantil de perspectivas bem distintas.

Para este trabalho, selecionamos apenas uma das produções feitas por alunos do quarto ano, depois de um encontro no qual falamos sobre os seres mitológicos. No conjunto produzido pelas crianças, vários seres foram desenhados: Minotauro, Centauro, Medusa, Sereia. Nesse dia, as crianças pediram para levar os desenhos para terminarem em casa, o que não era muito comum. Elas retornaram com os desenhos no encontro da semana seguinte e vimos que a maioria havia desenhado Sereias. Assim, escolhemos uma seção de desenhos sobre as Sereias para analisar. Examinamos os desenhos tanto na parte plástica quanto nas possíveis influências dos meios de comunicação de massa ou outras formas de influência no desenho dessas crianças.

Paralelamente a esse exercício, buscamos obras que falavam sobre as Sereias, sua genealogia, características físicas etc., e verificamos que os textos mais antigos, pelo menos os dois que conseguimos ter acesso, se referiam a dois poemas épicos: a Odisseia, de Homero - mais especificamente o livro XII, e a Metamorfose, de Ovídio - mais especificamente o livro V. Depois de analisadas essas obras, buscamos algumas imagens que pudessem esboçar tanto os acontecimentos quanto as personagens desses poemas. $\mathrm{O}$ intuito foi aproximar texto e imagem, buscando verificar como os artistas se apropriaram dos elementos textuais dos mitos das Sereias para construírem suas ilustrações, obras de arte e demais produtos culturais. 
Esse estudo insere-se na área de Educação, no que poderíamos chamar de educação visual. Não se trata de estudos de recepção de imagens, mas um trabalho de interpretação, de leitura das produções infantis e suas expressões gráficas por meio dos desenhos, bem como uma leitura sobre os produtos culturais selecionados. Durante a análise, buscamos ver o desenho e sua plasticidade, as escolhas feitas pelas crianças, algumas pistas sobre as influências da mídia ou de outros aspectos sobre seus desenhos; já quanto às imagens recolhidas na internet e em livros sobre esse tema, procuramos um diálogo com os diferentes autores sobre o desenho das crianças e a indústria cultural na perspectiva da educação visual.

\section{as sereias das crianças}

Os desenhos analisados neste trabalho foram produzidos por crianças do quarto ano do Ensino Fundamental, com idade entre oito e nove anos. Nesse encontro, falamos de algumas características dos seres mitológicos e foram mostradas algumas imagens de cada um dos seres.

A imagem da Sereia apresentada à turma foi uma pintura de John William Waterhouse, de 1901, por considerarmos importante aproximar as crianças das obras de arte. No entanto, não éramos conhecedores da genealogia das Sereias e de todas as formas de representação desse ser, naquela ocasião.

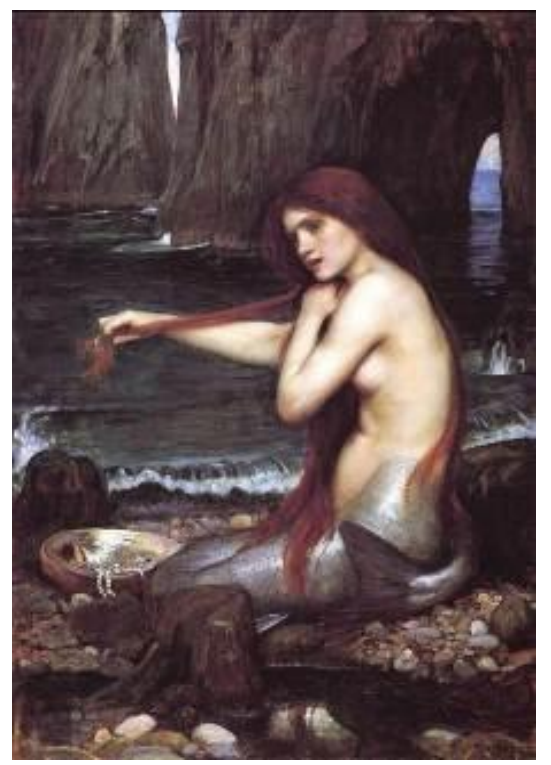

Figura 1 - The mermeid, por John William Waterhouse $(1901)^{5}$

\footnotetext{
${ }^{5}$ Fonte: http:/ / www.islandbreath.org/2013Year/09/130918mermaid.jpg 
As crianças produziram uma série de desenhos, todos eles, seguindo essa última forma de expressão de uma Sereia, com cauda de peixe. Vamos olhar alguns deles:

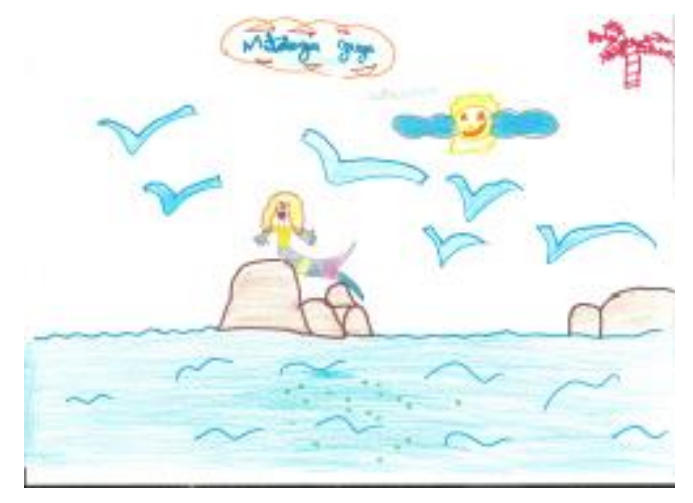

Figura 2: Sereia com cauda multicor desenho de uma criança do $4^{\circ}$ ano $^{6}$

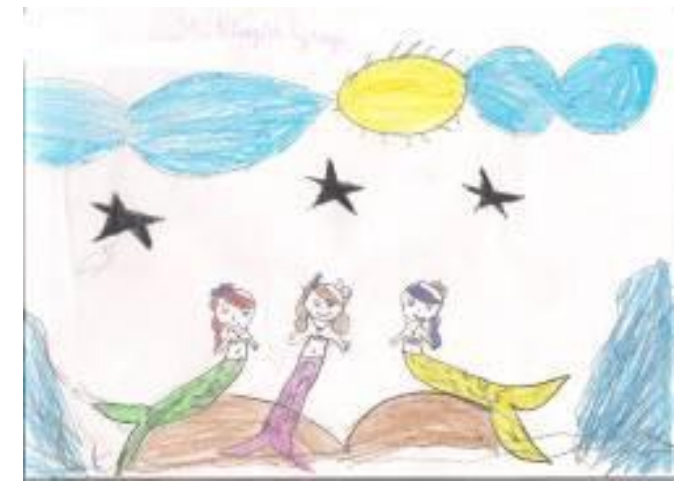

Figura 4: Três Sereias (Super Poderosas?) desenho de uma criança do $4^{\circ} \mathrm{ano}^{8}$

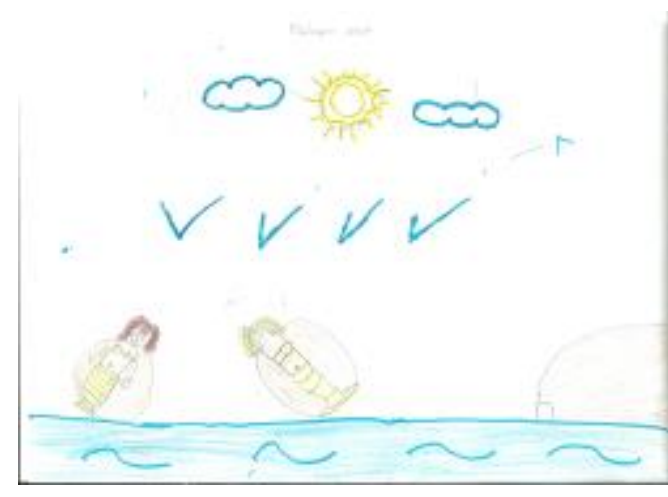

Figura 3: Duas Sereias lado a lado desenho de uma criança do $4^{\mathrm{o}} \mathrm{ano}^{7}$

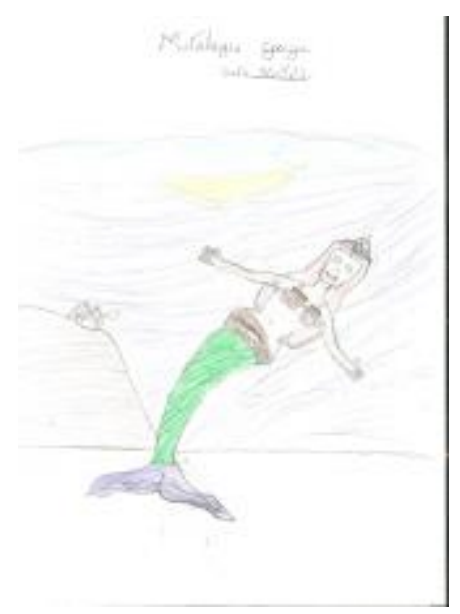

Figura 5: Sereia (Ariel?) desenho de uma criança do $4^{\circ}$ ano ${ }^{9}$

Temos aqui alguns exemplos dos desenhos que as crianças produziram a partir do encontro sobre seres mitológicos e que recortamos para pensar nessa produção de desenhos pelas crianças, sua estética, a evolução do grafismo e as possíveis influências dos meios de comunicação de massa nessa expressão infantil.

No que consiste ao aspecto plástico e artístico dos desenhos infantis, podemos verificar que as crianças usaram todo o limite da folha como limite do

\footnotetext{
${ }^{6}$ Fonte: Banco de dados da pesquisa

${ }^{7}$ Idem.

8 Ibidem.

${ }^{9}$ Ibidem.
} 
desenho, tiveram a preocupação de organizar as formas no espaço, relacionandoas e organizando-as por meio de uma linha imaginária. Usaram a folha sulfite ou "A4" tanto no sentido horizontal, como no vertical o que demonstra uma escolha, apesar de não haver muitas opções pela própria padronização do papel. Percebemos que a personagem principal, no caso a Sereia, está no centro da folha, no entanto, as crianças utilizaram as bordas do papel para colocar outros elementos no desenho, até mesmo um coqueiro lá no canto direito do papel, acima do sol e das nuvens, como pode ser visto na figura 2.

Não havia muitos materiais disponíveis em cada encontro, o que tínhamos era, basicamente, uma folha A4, lápis grafite, lápis de cor, giz de cera e canetinha hidrocor. A maioria desenhava com o lápis grafite e, posteriormente, coloria. Nesta seleção vemos o uso do lápis de cor e das canetinhas hidrográficas.

As Sereias por sua vez, foram coloridas de maneira bem diversificada. Algumas tinham os cabelos coloridos de amarelo, vermelho, marrom e roxo. As caudas prevaleciam verdes, o que não impossibilitou de observamos algumas amarelas, roxa e multicor. As Sereias foram desenhadas com sutiã e muitos acessórios: tiaras, colares, brincos, cintos e flores/laços no cabelo.

No cenário, as Sereias estavam acompanhadas de pássaros - a maioria em forma de " $\mathrm{V}$ ", coloridos na cor azul - e de caranguejo e golfinhos coloridos, respectivamente, na cor vermelha e rosa. Outras apareciam apenas na companhia de outras Sereias ou ainda sozinhas, sentadas ou deitadas sobre uma pedra. $\mathrm{Na}$ maioria dos desenhos, as cores dos elementos da natureza que compunham o cenário, foram mantidas conforme a forma tradicional (estereotipada ou clichê): sol amarelo, nuvens e mar azuis, pedra cinza ou marrom. Apenas o coqueiro foi feito com canetinha vermelha, fugindo ao estereótipo.

A presença do caranguejo na figura 5 é uma pista do ambiente cultural dessa criança. A cidade de Aracaju/SE é muito conhecida pela gastronomia feita com caranguejo. Há muitos manguezais e a presença desse crustáceo é bem comum entre os moradores. A criança deixou a sua marca cultural ali, ao desenhar junto à Sereia o caranguejo conhecido por ela. 
No diálogo com os autores, no que diz respeito à evolução do grafismo infantil, vimos que vários deles definem a evolução do desenho, tendo como base o aspecto cronológico, no entanto, não foi por essa via que julgamos mais profícua a nossa análise. Assim, buscamos fundamentar nossas análises em Iavelberg (2013, p. 11-12), que trabalha com a ideia de momentos conceituais, com invariâncias funcionais e diversidade cultural. Tais momentos, diz a autora, são edificados pelo sujeito da aprendizagem no diálogo com as culturas e nas situações educativas, denotando transformações de níveis de "menos saber" desenhista para outros de "mais saber", alcançados em múltiplas interações: do desenhista com sua própria produção e com a de seus pares, e ainda, com a produção sócio-histórica de diversos tempos e contextos culturais.

Partindo dessa concepção, Iavelberg cria um importante termo que atribuí ao conceito de desenho, fazendo com que ele ganhe outra conotação. Trata-se, pois, do termo cultivado que, em linhas gerais, refere-se aquilo que é objeto de cultivo, de cultura. Para a autora, "desenho cultivado" é um conceito por meio do qual é possível ver que, desde cedo, a criança observa e imita atos e formas de desenhos realizados em sua presença, incorporando-os em seu repertório por intermédio de assimilação recriadora.

Isso porque, desde cedo, a arte da criança sofre influência do ambiente em que vive e da cultura, tanto na escola, por intermédio da orientação que recebe e de materiais e suportes que usa para realizar seus trabalhos, quanto através de imagens e atos de produção artística que observa na TV, internet, gibis, rótulos, estampas, obras de arte, vídeos, trabalhos de outras crianças, e ainda da observação que faz do entorno ambiental etc., como pode ser visto no desenho com o caranguejo (figura 5).

Para Iavelberg (2004), a criança é autônoma ao fazer seus trabalhos artísticos, ainda que os faça de maneira cultivada, isto é, denotando a influência cultural que recebe, pois ela revela: o local e a época histórica em que vive, suas oportunidades de aprendizagem, suas ideias ou representações sobre o trabalho artístico que realiza e sobre a produção de arte à qual tem acesso, seu potencial 
para fazer trabalhos artísticos e refletir sobre a produção pessoal e social de arte. Como bem esclarece a autora,

Considera-se que, ao desenhar, a criança use cognição e sensibilidade somadas à experiência que tem diretamente com desenho no contexto sócio-histórico e cultural em que vive, por si ou com mediação de outros (crianças e adultos). Não se deve deixar de observar que o fato de a criança sofrer influência das culturas, fenômeno incorporado pelas didáticas contemporâneas da arte, não significa perda da liberdade de seleção e escolha do sujeito criador nos atos de aprendizagem. Em outras palavras, não se trata de aprender a desenhar relendo ou copiando modelos de imagens da arte, ou seguindo passos impostos pelo professor para aprender a fazer determinados desenhos, mas de assimilá-los aos próprios esquemas desenhistas, no contato com códigos da linguagem, gerados nas diferentes culturas e épocas, em sua abertura à singularidade dos desenhistas individuais, que desenvolvem seus percursos de criação pessoal, agora informados pelas culturas (IAVELBERG, 2013, p. 25).

Há autores que veem o desenho infantil sob a influência do contexto sóciohistórico e cultural, sem grandes problemas, pois, como Iavelberg, acreditam que a criança é capaz de apropriá-los sem grandes perdas no seu processo de criação e originalidade. No entanto, observamos que, infelizmente, a depender das oportunidades que as crianças têm, em relação ao repertório cultural a que tem acesso, suas produções podem sofrer uma influência negativa e limitar seu potencial criativo.

Alguns exemplos foram encontrados nos desenhos analisados, pois observamos que as crianças foram influenciadas por imagens e desenhos ditos "para colorir", apreendendo apenas a forma imagética que é exaustivamente reproduzida pela mídia, em que as Sereias são representadas hegemonicamente com cauda de peixe. Acreditamos que essa forma de expressar as Sereias, também pode ter sofrido influência da obra que apresentamos, que reforçava essa representação da Sereia com cauda de peixe. 


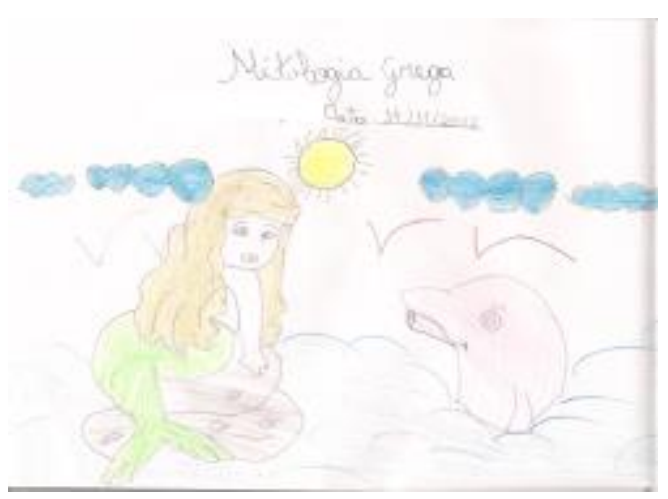

Figura 6: Sereia (cópia) desenho de uma criança do $4^{\circ}$ ano ${ }^{11}$

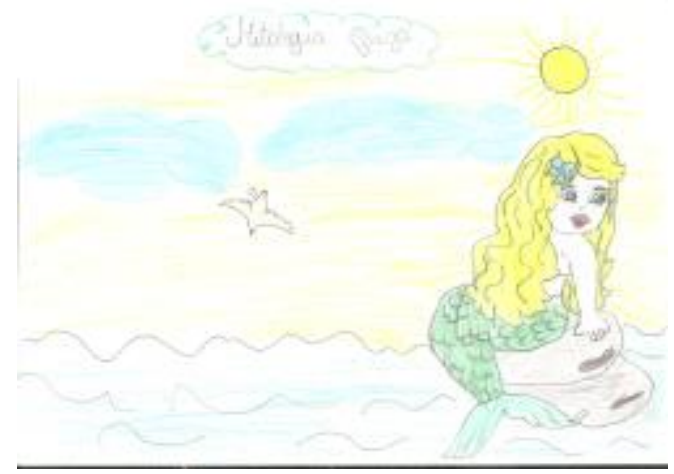

Figura 8: Sereia (cópia) desenho de uma criança do $4^{\circ}$ ano ${ }^{13}$

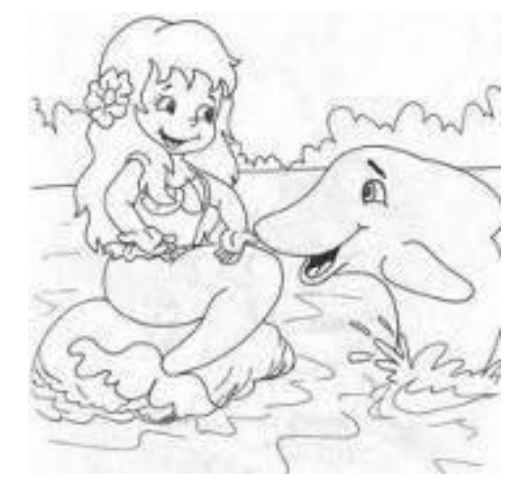

Figura 7: Desenho para colorir (Sereia) $)^{10}$

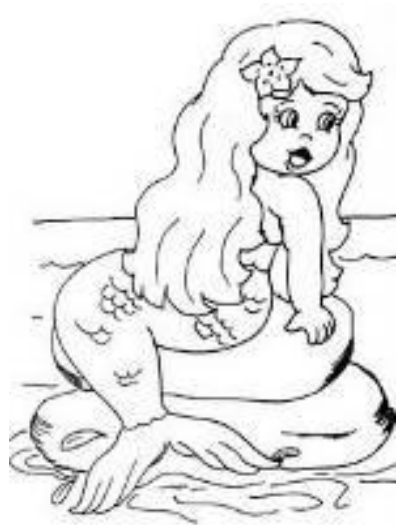

Figura 9: Desenho para colorir (Sereia) ${ }^{12}$

Na figura 6 vemos o golfinho, que pode ter sido copiado da figura 7, mas utilizado a Sereia da figura 9, ambos retirados de sites indicados para pais e professores para imprimirem desenhos para as crianças colorirem. A fonte da figura 9 é um site criado por uma professora que dá várias dicas de aulas prontas, lembrancinhas para datas comemorativas e desenhos de diversos temas, prontos para imprimir e colorir.

Percebemos que as crianças tiveram acesso a esse material e isso nos mostra como a redução a esta única forma de representação, padronizou e empobreceu o modo como as crianças expressaram em seus desenhos as Sereias,

\footnotetext{
${ }^{10}$ Fonte: http://coisaspraver.blogspot.com.br/2013/08/desenhos-do-folclore-brasileiro-para.html

${ }^{11}$ Fonte: Banco de dados da pesquisa

${ }^{12}$ Fonte: http:// www.ensinar-aprender.com.br/2011/08/desenhos-para-colorir-da-Sereiaiara.html

${ }^{13}$ Fonte: Banco de dados da pesquisa
} 
bloqueando a criatividade e estabelecendo uma forma "certa" e "errada" de desenhar essas personagens míticas.

Também podemos questionar a "cópia" ou a "imitação", dois conceitos trabalhados por alguns autores que se dedicaram a estudar o desenho infantil. Segundo Derdyk (2010), a imitação possui um significado diferente da cópia. Para a autora, a imitação decorre da experiência pessoal da criança, orientada pela escolha própria que ela faz dos objetos, para então apropriar-se de determinado conteúdo, forma, figura ou tema através da representação.

Já a cópia, implica a ausência de originalidade e de criatividade, pois é mera reprodução impessoal e revela um distanciar-se de si mesmo. Como nos diz Derdyk (2010, p. 105), “Ensinar a criança a copiar é ensinar a estereotipia, é esvaziar o sentido da pesquisa natural. O campo do imaginário se vê às voltas com fiscais introjetados controladores da ação gráfica, desenvolvendo na criança uma crítica censora": eu não sei desenhar!

A exceção da estereotipia acontece quando a criança rompe com o paradigma pré-determinado da cor, da forma e de certos elementos predominantes no meio cultural e começa a expressar sua imaginação de maneira subjetiva, do jeito como apreende o mundo ao seu redor, expressando assim seus sentimentos, vontades, ideias etc. Todavia, esta maneira de se expressar mais livremente é repreendida e influenciada tanto pela escola (colegas e professores), pela família (pais, irmãos etc.), que tentam estabelecer para a criança um modo "correto" de desenhar e colorir, quanto pelos meios de comunicação em massa, que povoam o imaginário infantil com seu manancial de imagens. Assim,

É preciso, pois, acabar com um certo mito da espontaneidade infantil: dotar a criança de reações inocentes e gratuitas leva a ignorar o papel da imitação na sua formação e desenvolvimento. A conduta da criança tanto no plano gráfico quanto nos outros domínios - comporta clichês, citações, imagens emprestadas. Quem esteve em contato com crianças ou então manipulou uma grande quantidade de desenhos, sabe bem que nem todos demonstram uma expressão espontânea. A utilização de estereótipos, a imitação e a cópia são frequentes, e uma das principais dificuldades com as quais se defrontam os métodos "de expressão livre" está precisamente na amplidão e na profundidade do condicionamento ao qual a criança está submetida (MÈREDIEU, 2006, p. 102). 
desenho infantil e produtos culturais: como aparecem as sereias?

Pudemos perceber as diferentes expressões das crianças no primeiro conjunto (figura 2 a figura 5), no entanto com um repertório que poderíamos dizer ser clichê ou ainda comum ao repertório de desenhos infantis. Talvez uma citação das "Meninas Super Poderosas" na forma de Sereias (figura 4), como sendo uma releitura de um produto cultural consumido por ela. Nesse sentido, não estamos tocando apenas na questão de cópia ou imitação, mas na possível influência dos meios de comunicação de massa.

Publicidade, cinema, televisão, revista em quadrinhos [e, sobretudo, internet] assaltam constantemente a criança; [...] Os cartazes publicitários atraem o olhar da criança: grafismo despojado, cores vivas, formato grande, impressionam vivamente sua imaginação, visto que a elaboração da imagem publicitária apela para mecanismos inconscientes. [...] Não é, pois, surpreendente que o desenho seja povoado por heróis de novelas ou de histórias em quadrinhos [...] (MĖREDIEU, 2006, p. 106-109).

Para Mèredieu (2006), o problema da referência à atualidade não se coloca da mesma maneira nas diferentes idades. De três a cinco anos, esta influência é praticamente nula, pois a criança tira do repertório clássico temas infantis (figuras humanas, casa, navio, sol, animais etc.). O egocentrismo próprio da fase, diz a autora, isola a criança no seu universo e torna-a pouco sensível às solicitações do universo do adulto. No entanto, esse repertório permanece, mesmo depois dessa idade, como podemos ver nos exemplos de desenhos que selecionamos para esse texto. Depois dos cinco anos, principalmente com a entrada na escola, a aprendizagem da leitura e a descoberta de um universo até então inimaginado amplia o repertório da criança. O valor social de alguns objetos e de alguns temas é reconhecido e explorado. O desenho torna-se, então, o eco dos acontecimentos, modificando ou acentuando a vida social e política que a criança exprime com seus meios técnicos próprios, utilizando um conjunto de estereótipos culturais, profundamente marcados pela cultura a qual pertence. Isso mostra que não podemos falar de "mito da espontaneidade infantil", pois é visível o quanto a criança é influenciada pelo meio.

No que diz respeito ao "mito da espontaneidade infantil" proposto por Mèredieu (2006), Iavelberg nos diz:

Essa crença no desenho espontâneo, embora considere alguns dados que promovem sua evolução, leva a autora a atribuir a fatores educacionais e 
sociais o empobrecimento e o desparecimento do desenho da criança. Afirma que a 'desgestualização' progressiva da arte infantil se deve à função repressiva do adulto e à tendência cultural-narrativa da arte. [...] Interessante notar que a autora valoriza os movimentos de recuperação da gestualidade da Arte Contemporânea ao mesmo tempo em que situa a criança à margem da produção social, como se sua produção fosse paralela e se comportasse de maneira alienada em relação aos modelos e ideias sobre arte no meio em que convive." (IAVELBERG, 2013, p. 45)

O que Iavelberg quer ressaltar é que, independente da criança copiar modelos estereotipados ou seguir passos impostos pelos adultos para fazer seus desenhos, a construção do desenho é simultaneamente biológica e cultural, desde os primórdios. A cultura sempre se fez presente na apresentação e seleção de meios e suportes, e na observação dos atos de desenho. Por isso é que o desenho cultivado expressa a síntese dos esquemas de desenho do sujeito e esses esquemas são construídos de forma ativa, o que envolve sua interação com os sistemas de desenho em desenvolvimento no meio sociocultural.

Iavelberg também irá tratar da "estagnação do processo criativo" das crianças em relação ao desenho. A autora menciona a insegurança de crianças de educação infantil com os resultados de seus desenhos e diz que "talvez isto se deva à precocidade com que são expostas a um excesso de imagens visuais pela mídia, sem trabalho orientador de leitura e desenvolvimento de percurso de criação pessoal" (IAVELBERG, 2013, p. 57). Neste sentido, a presença do professor poderia ampliar o repertório imagético das crianças, discutindo as formas expressivas em que diferentes temas aparecem na mídia. Caso contrário, o professor contribui para bloquear a criatividade do aluno, que sob a influência estética adulta, apropria-se de modelos visuais muitas vezes estereotipados e que limitam as possibilidades de expressão. No entanto, interrogamos: e quando o professor cria um site com dicas para aqueles profissionais que não tem tempo para pensar em suas aulas e pode recolher ali desenhos para colorir, atividades práticas para suas aulas e lembrancinhas para datas comemorativas, entre outras coisas?

A influência é certa, a julgar por nosso exemplo: ao levarmos para a escola uma pintura que mostrava uma Sereia com cauda de peixe, sem ter a intenção de influenciar, acabamos por fazer exatamente isso, influenciamos as crianças a 
seguirem a mesma forma imagética da Sereia presente na pintura. Nem nós conhecíamos outras formas de expressão e representação desses seres. Sabíamos que eram seres mitológicos e tivemos as melhores intenções ao levar isso para a escola, depois de percebermos o interesse e a curiosidade dos alunos.

Mas, quem são as Sereias? Também nós não contribuímos como poderíamos ter contribuído para a ampliação desse repertório cultural e imagético das crianças, como poderemos ver agora, nos desdobramentos da pesquisa.

\section{outras sereias}

Sirenas, sirenes ou Sereias ( $\varepsilon \varepsilon \rho p \dot{\eta} v$, Seirến, em grego, sirens, em inglês) são seres mitológicos femininos, capazes de encantar qualquer um que ouvisse o seu canto, representados sob a forma de peixe ou ave, com cabeça e/ou busto de mulher.

Segundo a literatura, sua genealogia é um pouco confusa, mas em geral são consideradas filhas de Aquelóo (Deus-Rio) e da musa Calíope (A Bela Voz), ou da musa Terpsícore (A Rodapiante) ou ainda da musa Melpômene (A Poetiza). Alguns autores as consideram como filhas de Gaia (Mãe Universal, conhecida também pelas infalíveis profecias), o que justifica elas poderem prever o futuro.

Segundo Commelin (1997), na maioria das histórias, as Sereias são representadas em número de três, sendo elas: Lígia (A Melodiosa), Leucósia (A Brancura) e Partênope (A Aparência Jovem). Diz-se que, a primeira lia textos e cantos, a segunda, tocava flauta e, a terceira, tocava lira.

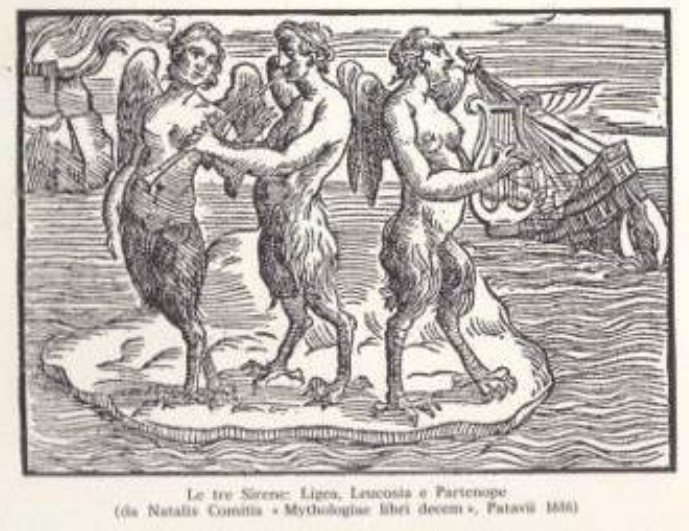

Figura 10 - Le tre Sirene: Ligia, Leucosia e Partenope, por Patavii (1616) ${ }^{14}$

\footnotetext{
${ }^{14}$ Fonte: http:/ / www.sgdl-auteurs.org/maria-franchini/public/Fetes/7.jpg
} 
A imagem nos dá a ver a descrição feita por Commelin. Mas, além dos instrumentos musicais, as pernas de galinha ou ave com o dorso feminino, chama muito a atenção. Além disso, estão numa ilhota que mal cabem as três, rodeada por um mar com uma embarcação afundada. Vários elementos que compõem essa história das Sereias podem ser vistos, portanto, numa única imagem.

Já outras histórias, se referem a essas três Sereias como Aglaofane (A Bela Voz), Telxiêpia (A Encantadora) e Pisínoe (A Persuasiva). Geralmente, essas Sereias impunham em suas mãos os seguintes instrumentos: uma espécie de flauta de bico ou um rolo, uma lira e duas flautas. Na imagem a seguir, as Sereias estão tocando para a tripulação da embarcação de Ulisses. Há uma proximidade muito grande do barco com a pequena ilha pedregosa onde as sereias, com roupas e véus, tocam. Todas mostram os pés descalços. Aqui não há a representação das Sereias como aves ou peixes, mas com a forma humana.

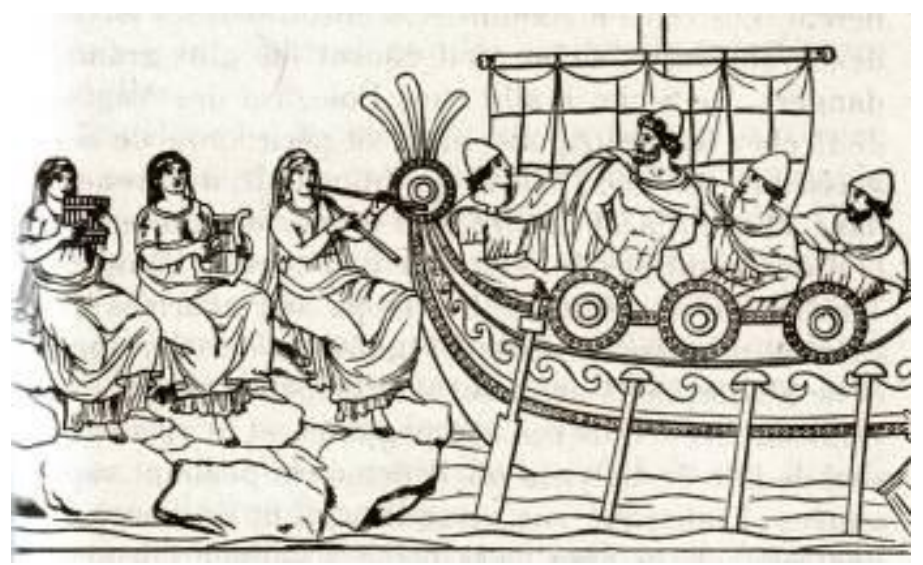

Figura 11 - As Sereias encantando os marinheiros, autor desconhecido (s.d.) $)^{15}$

Além dessas Sereias, existe o relato de outras com nomes e epítetos diferentes, tais como: Aglaope (A Bela Aparência), Himéropa (A Doce), Diopátre (A Divina), Thelxíno (A Perturbadora), Molpe (O Estranho Canto), Raidné (O Progresso) e Thysa (O Frênesi) - denominações que também exprimem o encantamento e doçura da voz.

\footnotetext{
${ }^{15}$ Fonte: http:// marikavel.org/grece/sirene-harpe-com373.jpg
} 
Embora ligadas ao mar e às viagens marítimas, as Sereias não eram entidades marinhas. Commelin nos diz que elas eram belas jovens do séquito de Perséfone/ Prosérpina (deusa da germinação e das sementes). Na época em que Hades (deus dos mortos) raptou essa deusa, as Sereias foram à terra de Apolo (deus da luz, das artes, da profecia) pedir ajuda para encontrar sua companheira, mas Deméter (deusa da terra cultivada), irritada por não terem impedido o rapto da filha, as transformou em pássaros. Já Ovídio, conta que as Sereias, desoladas com o rapto de Perséfone, rogaram aos deuses que lhes dessem asas para irem procurar sua jovem amiga por toda a terra, no céu e no mar.

Que razão havia para dar às filhas de Achelous penas e garras, mas deixando-as ainda com o rosto que tinham? Teria sido porque estavam com Prosérpina, quando ela colhia aquelas flores fatídicas? Eram suas amigas queridas, as Sirenes, feitas para cantar, e elas a seguiram por todas as terras, em vão, e chegaram até o oceano e rezaram para conseguir encontrá-la ali, pediram asas para sobrevoá-lo, e planaram sobre as águas. Os deuses foram bondosos e lhes deram plumagens douradas, e permitiram que conservassem suas adoráveis vozes, tão agradáveis aos ouvidos dos homens, e também suas feições humanas (OVÍDIO, 2003, p.108).

Nessa imagem podemos ver as Sereias como criaturas com feições humanas, asas, rabos e pés de animais. Elas sobrevoam a cena do rapto que está acontecendo, numa bela obra de Luca Giordano.

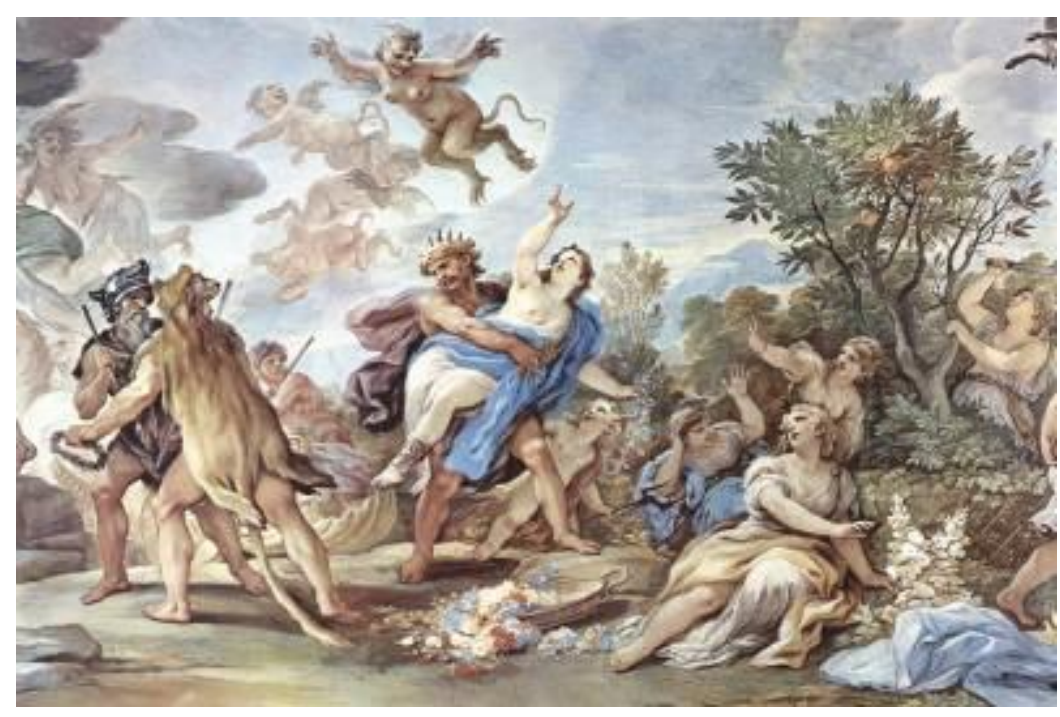

Figura 12 - O rapto de Proserpina, por Luca Giordano (1684-1686) ${ }^{16}$

\footnotetext{
${ }^{16}$ Fonte: http://spf.fotolog.com/photo/31/42/114/donaluz/1260708042598_f.jpg
} 
Em outra versão, diz-se que Afrodite transformou as Sereias em aves por elas desprezarem os prazeres do amor, por isso tornou-as frígidas da cintura para baixo. As Sereias então desejavam o prazer, mas não podiam usufruí-lo e, por isso, atraíam e prendiam os homens para devorá-los.

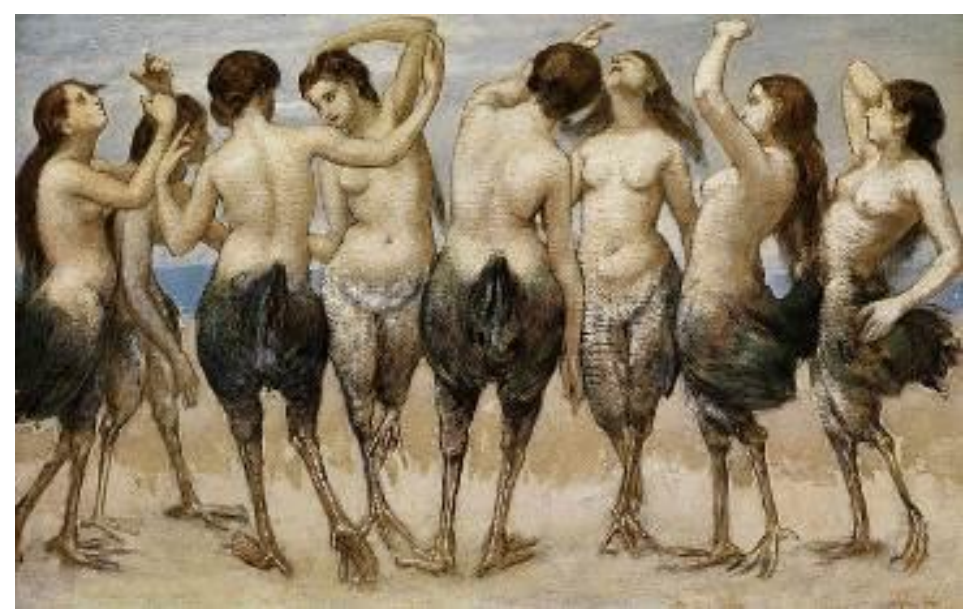

Figura 13 - Mulheres dançando em corpos de aves, de Hans Thoma (1886) ${ }^{17}$

Remetendo-se a Pausânias, Commelin conta a versão de que as filhas de Aquelóo, incentivadas por Juno, pretenderam a glória de cantar melhor que as Musas (deusas da música, da inspiração poética e da rememoração) e ousaram desafiá-las; mas as Musas, tendo-as vencido, arrancaram-lhe as penas das asas e, com elas, fizeram coroas para si.

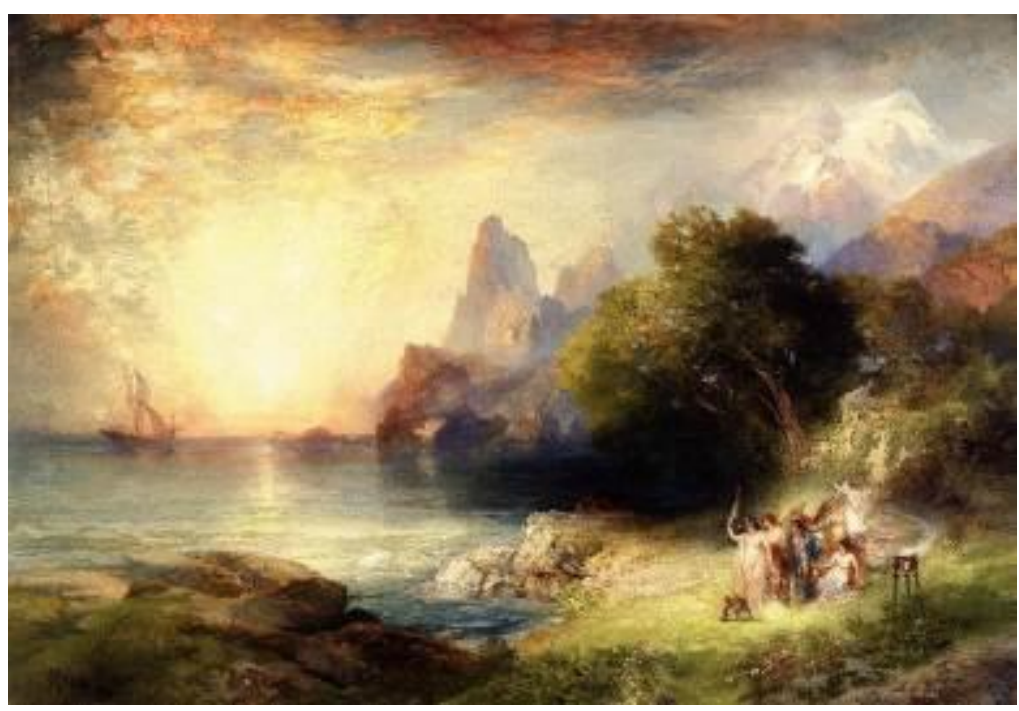

Figura 14 - Ulysses and the sirens, por Thomas Moran $(1900)^{18}$

\footnotetext{
${ }^{17}$ Fonte: http://upload.wikimedia.org/wikipedia/commons/d/d2/Hans_Thoma__Acht_tanzende_Frauen_in_Vogelk\%C3\%B6rpern.jpg

18 Fonte: http://pt.wahooart.com/Art.nsf/O/8BWW2F/\$File/Thomas-Moran-Ulysses-and-theSirens.JPG
} 
Segundo contam, as Sereias viviam em uma ilha do Mediterrâneo, cercada de rochas e recifes e de localização variável, de acordo com a versão do mito. Os marinheiros que se aproximavam o bastante para ouvir seus suaves e hipnóticos cantos descuidavam-se e naufragavam. Alguns autores tardios relatam que elas devoravam os marinheiros afogados, mas é provável que essa informação venha de uma interpretação errônea da Odisseia, diz Commelin. Um oráculo predissera às Sereias que elas viveriam enquanto pudessem deter os viajantes à sua passagem, mas que, tão logo um só passasse sem ser detido pelo canto das suas vozes e das suas palavras, elas pareceriam.

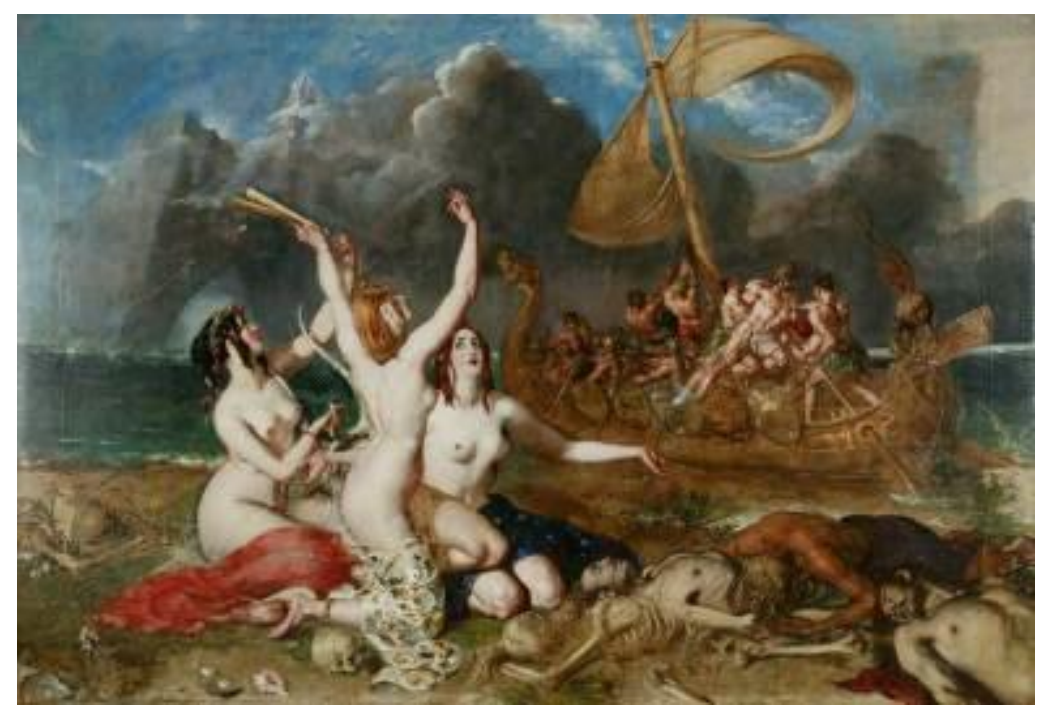

Figura 15 - The Sirens and Ulysses, por William Etty $(1837)^{19}$

Essas encantadoras criaturas, sempre despertas, não deixavam de deter, com sua harmonia, todos os que chegavam perto delas e que tinham a imprudência de ouvir seus cantos. Elas os enfeitiçavam, os encantavam a tal ponto que eles não pensavam mais em seu país, em sua família, em si mesmos; esqueciam-se de beber e de comer e morriam por falta de alimento. A maioria das versões conta que a costa vizinha era toda branca das ossadas dos que haviam perecido assim.

\footnotetext{
${ }^{19}$ Fonte:

http://upload.wikimedia.org/wikipedia/commons/8/8f/The_Sirens_and_Ulysses_by_William_ Etty,_1837.jpg
} 
No entanto, quando os Argonautas passaram por suas paragens, elas fizeram esforços inúteis para atraí-los. De pé no barco, Orfeu (o mais conhecido dos músicos lendários da Grécia Antiga) pegou da sua lira e encantou-as, a tal ponto que elas permaneceram mudas e jogaram seus instrumentos no mar. Alguns autores acrescentam que, ao falharem, as Sereias afogaram-se ou transformaramse em rochas, situando esse episódio na história dos Argonautas; outros, nas viagens de Odisseu ou Ulisses.

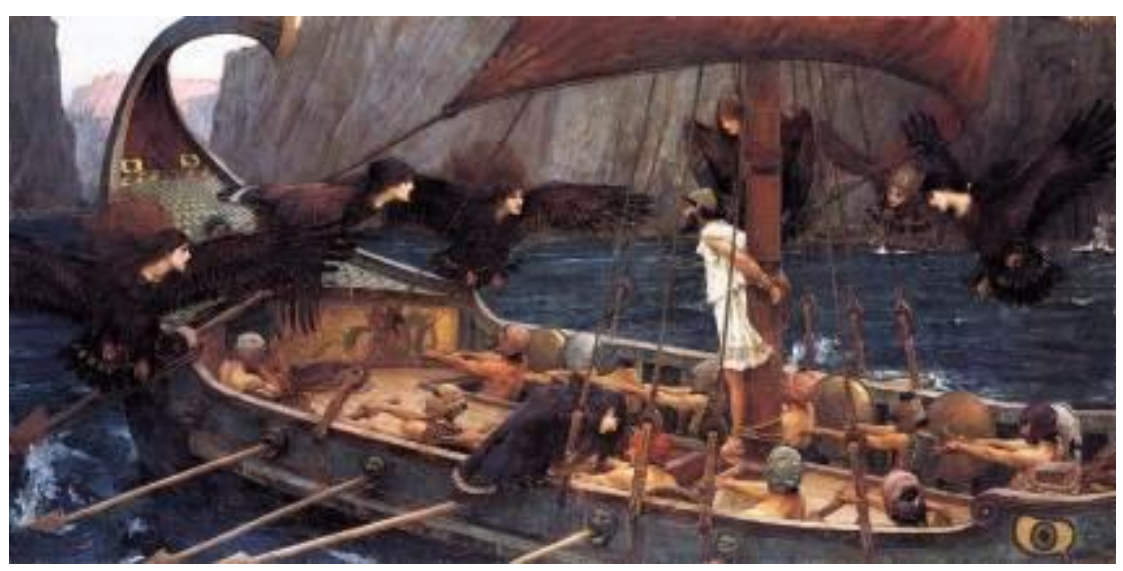

Figura 16 - Ulises e las Serenas, por John William Waterhouse $(1891)^{20}$

Na Odisseia conta-se que Ulisses, obrigado a passar com seu navio diante das Sereias e advertido por Circe (uma feiticeira) sobre esse evento, tapou os ouvidos de todos os seus companheiros com cera e fez-se amarrar num mastro pelos pés e pelas mãos. Ademais, proibiu que o soltassem caso ouvissem a voz das Sereias e ele exprimisse o desejo de parar. Tais precauções não foram vãs. Mal ouviu aquelas encantadoras criaturas, suas doces palavras, suas promessas sedutoras, Ulisses, apesar do conselho que recebera e da certeza de perecer, intimou seus companheiros a soltá-lo, o que, felizmente, eles evitaram fazer.

Vem aqui, decantado Ulisses, ilustre glória dos Aqueus; detém tua nau,
para escutares a nossa voz. Jamais alguém por aqui passou em nau
escura, que não ouvisse a voz de agradáveis sons que sai de nossos
lábios; depois afasta-se maravilhado e conhecedor de muitas coisas,
porque nós sabemos tudo quanto, na extensa Tróade, Argivos e Troianos
sofreram por vontade dos deuses, bem como o que acontece na nutrícia
terra". Assim elas cantavam, e suas magníficas vozes inundavam-me o
coração com o desejo de as ouvir, de sorte que, com um movimento das
sobrancelhas, ordenei aos companheiros que me soltassem; eles, porém,
curvados sobre os remos, continuavam remando; mas, imediatamente,

${ }^{20}$ Fonte: http:/ / wall.sf.co.ua/12/10/wallpaper-2379234.jpg 
Perímedes e Euríloco, tendo-se levantado, prenderam-me com laços mais numerosos e os apertaram com mais força. Depois que passamos as Sereias e não mais lhe ouvimos a voz nem o canto, meus fiéis companheiros retiraram a cera, com que lhes tapara os ouvidos, e libertaram-me as cordas. (HOMERO, 2003, p. 160-162).

Algumas versões ainda dizem que, não podendo deter Ulisses, as Sereias se precipitaram no mar. Por causa disso, as pequenas ilhas rochosas que habitavam, diante de uma península da Lucânia, foram chamadas de Sirenusas.

Com base nas versões que são contadas ao longo do tempo, podemos observar que algumas Sereias são representadas ora com uma cabeça de mulher e um corpo de pássaro, ora com o busto de mulher e a forma de ave, da cintura aos pés. Às vezes, são representadas também com braços e pés, conforme a figura humana.

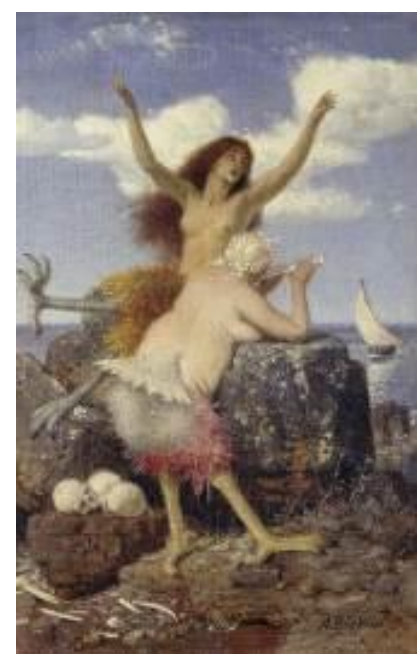

Figura 17 - Sirenen, por Arnold Böcklin (1875) $)^{21}$

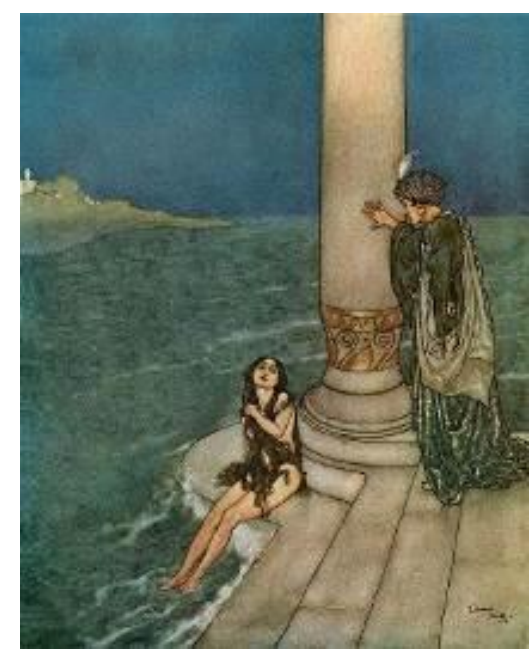

Figura 18 - The Mermaid - The Prince, por Edmund Dulac (1911) 22

Segundo Vaz (2012), muitas Sereias foram pintadas segurando um espelho e, não há um só autor antigo que nos tenha representado as Sereias como mulheres-peixe. Parece que essa característica só foi adotada a partir da Idade Média, dado que podem ser vistas em muitos manuscritos da época.

\footnotetext{
${ }^{21}$ Fonte: http://www.aerzteblatt.de/bilder/2013/05/img49889300.jpg

${ }^{22}$ Fonte: http://i.imgur.com/V0SXYs5.png
} 


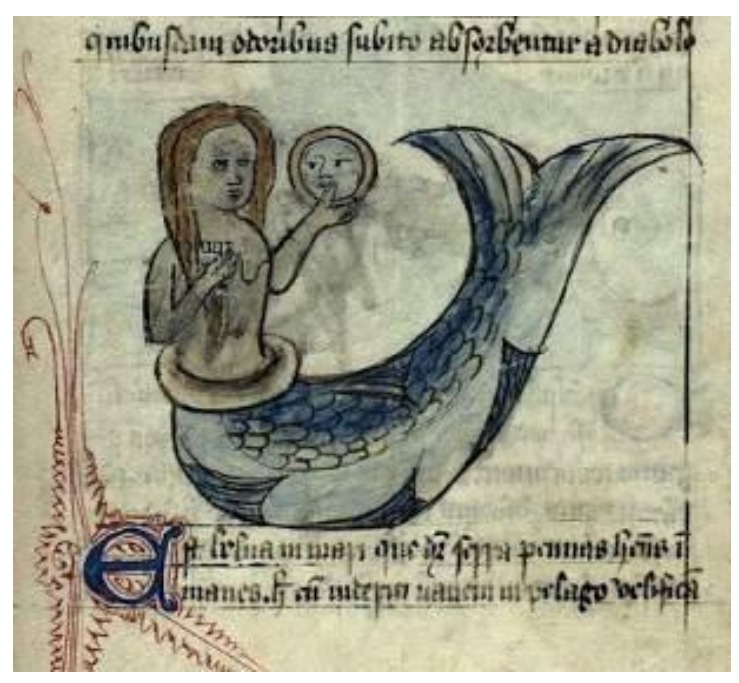

Figura 19 - Sereia com espelho, manuscrito inglês (séc. XV) ${ }^{23}$

Já em nossa época, a indústria cultural se apropriou das imagens das Sereias dando a elas novas roupagens mais adequadas aos interesses comerciais. Sem percebermos, as Sereias continuam seduzindo com seu belo canto e iludindo os desavisados, sejam eles adultos ou crianças. Como diz Vaz (2012, s.p.),

Desenganem-se os que creem que as Sereias levam vida fácil. Para chegarem até hoje, terão sobrevivido a oligarquias, monarquias, repúblicas, às grandes revoluções e às guerras mundiais. Contra todas as probabilidades, atormentadas pelos deuses antigos, superadas por Orfeu e Ulisses, depois condenadas pela moral cristã, ultrapassadas e dissecadas pela ciência das Luzes, as Sereias sobreviveram. Não consta que algum especialista se tenha debruçado sobre os efeitos das alterações climáticas ou das marés negras nestes seres delicados. A prova do seu sucesso: incorporam as suas histórias no mundo actual, principalmente na arte.

As Sereias continuam sendo produzidas e adaptadas no mundo contemporâneo por vários artistas, designers, ilustradores, publicitários como podemos ver:

${ }^{23}$ Fonte: https://www.flickr.com/photos/23307082@N07/3287698612 


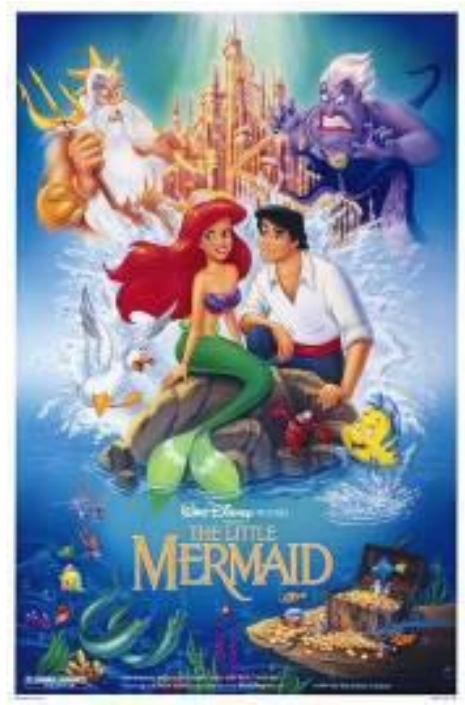

Figura 20 - The Little Mermaid, por Walt Disney Pictures (1989) ${ }^{24}$

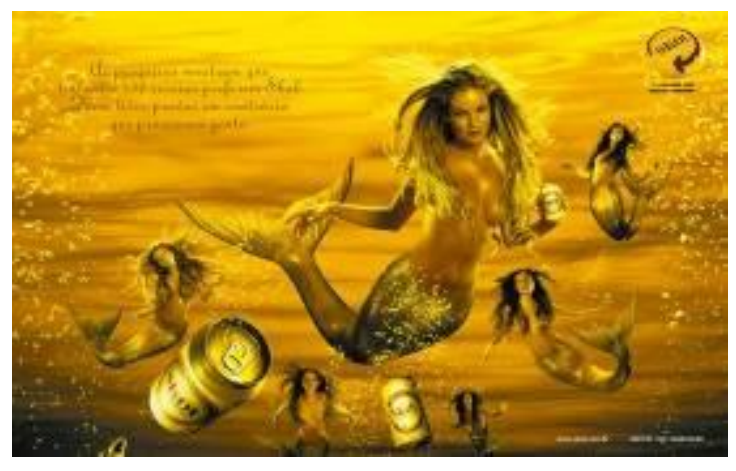

Figura 22 - Propaganda da Skol Pilsen²6

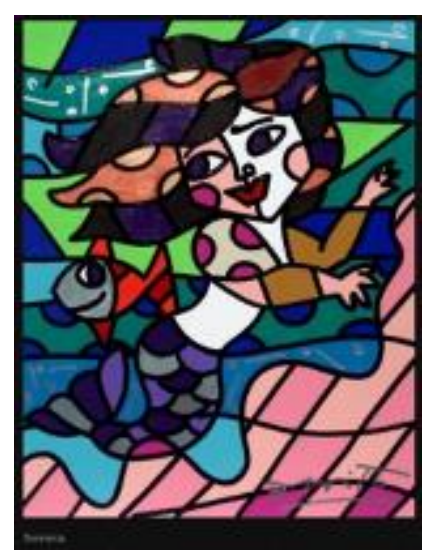

Figura 23 - Sereia, por Romero Britto (s.d.) ${ }^{27}$

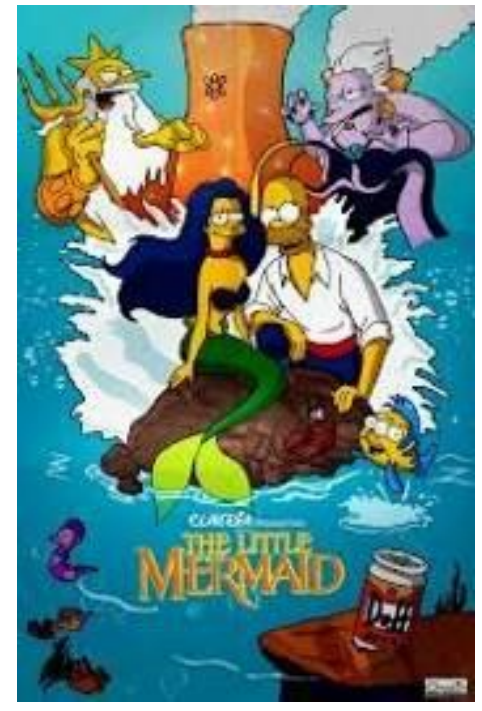

Figura 21 - The Little Mermaid, releitura Simpson (s.d.) ${ }^{25}$

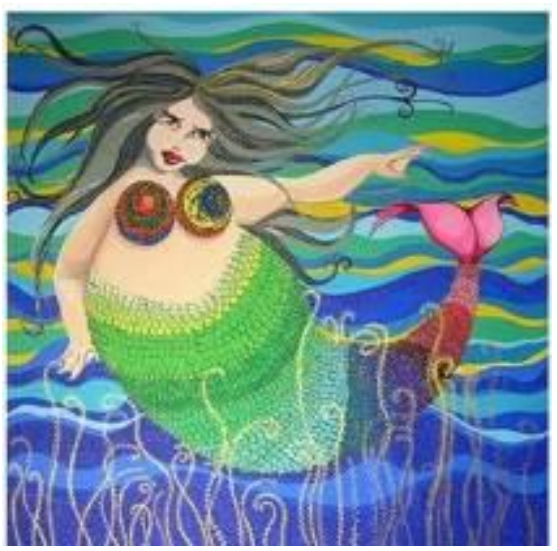

Figura 24 - Sereia, por Regina Kioko (s.d.) ${ }^{28}$

${ }^{24}$ Fonte: http://www.disneydreaming.com/wp-content/uploads/2010/11/The-Little-MermaidMovie-Poster.jpg

${ }^{25}$ Fonte: http:// mondovazio.virgula.uol.com.br/wp-content/uploads/2013/02/a-pequena-Sereiamarge-simpson.jpg?0abdf0

${ }^{26}$ Fonte: http://www.fnazca.com.br/wp-content/uploads/2009/11/_0102.jpg

${ }^{27}$ Fonte: http://www.bloginforma.com.br/romero-brito-um-homenageado-no-carnavalcarioca/Sereia/ 
Além dos Simpsons, Romero Britto, Disney e publicitários da marca Skol, um grande artista contemporâneo também trabalhou com o tema da Sereia em uma de suas telas:

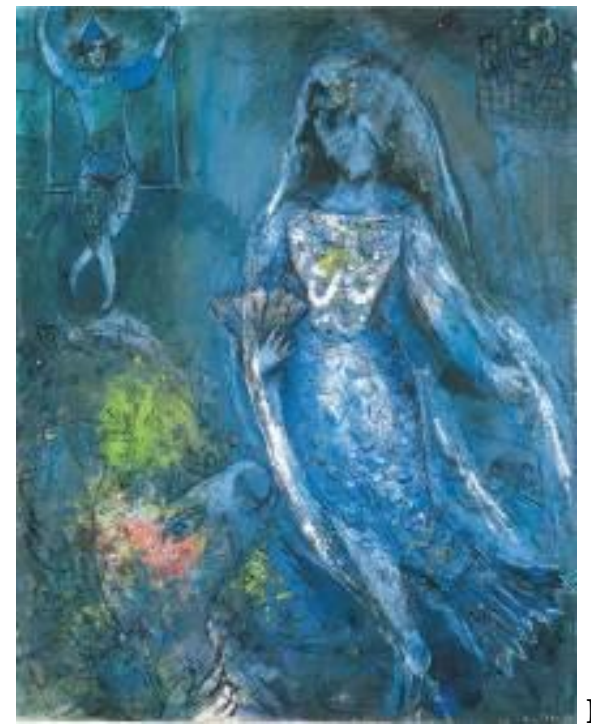

Figura 25 - La Sirène, por Marc Chagall (1945). ${ }^{29}$

As cores, a disposição dos elementos, a transparência que podem ser vistas neste trabalho de Chagall é muito diferente das últimas imagens vistas, principalmente dos desenhos animados e da propaganda publicitária, que marcam muito uma forma de representar as coisas, as pessoas ou seres e o mundo. Nessa tela, a Sereia tem pé e cauda, ao mesmo tempo. Ela veste um vestido longo, tem um véu na cabeça e segura um buquê (uma Sereia noiva?). Além da Sereia, outros elementos: um animal, um pierrô, um grupo numa embarcação (seria Ulisses?).

\section{algumas considerações}

Dos livros às telas a "sedução" do universo imagético oferecido, sobretudo pela indústria cultural, tanto pode atrapalhar quanto ampliar as possibilidades do desenvolvimento infantil. Isto se justifica, porquanto as crianças que consomem estes produtos culturais são atravessadas por imagens, sons, cores, palavras, que povoam o imaginário e podem tornar estéril a capacidade criativa destas crianças ao estabelecer modelos padrões que devam ser copiados e reproduzidos. Este

\footnotetext{
${ }^{28}$ Fonte: http://i963.photobucket.com/albums/ae114/falcaochoque/aSereia.jpg

${ }^{29}$ Fonte: http:// www.christies.com/lotfinder/lot/marc-chagall-la-sirene-4702181details.aspx?intObjectID $=4702181$
} 
fenômeno da cultura de massas traz implicações que devem ser problematizadas, principalmente no que diz respeito à influência dos meios de comunicação de massa na formação de um repertório cultural dessas crianças e as possíveis contribuições para a construção de suas subjetividades.

Sabemos que não é possível generalizar a influência da mídia em torno da produção gráfica infantil, partindo apenas da análise desses desenhos. Mas, nos interessa mostrar aqui que, dentre um conjunto limitado de desenhos, eles se destacaram por apresentar elementos "copiados" de imagens veiculadas pelos meios de comunicação de massa, no caso o desenho para colorir que as crianças tiveram acesso, seja na escola ou em casa. O acesso a esses desenhos e a cópia feita por várias crianças, lembrando que aqui só mostramos dois deles, contribuem para pensarmos em uma educação visual que está sendo construída com o auxílio dos meios de comunicação de massa e dos vários produtos culturais a que elas têm acesso.

Como descreve Almeida (1994, p. 46), “[...] a sociedade de massa é uma sociedade da visibilidade: adquire caráter de verdade instantânea aquilo que é mostrado, visto, ouvido". Embora esse artigo trate com maior ênfase da influência da indústria cultural sobre as produções infantis, tanto adultos quanto as crianças são vulneráveis àquilo que consomem, pois caracterizam-se como seres orais, seres que se (in)formam através das imagens e sons de inúmeros produtos da indústria cultural.

Em uma turma com crianças entre oito e nove anos, temos diferentes graus evolutivos do grafismo e também diferentes aproximações com os produtos culturais. Algumas nunca tinham ouvido falar sobre mitologia, seres e personagens míticos; já outras, tinham uma aproximação com este universo através de animações, propagandas, jogos eletrônicos entre outros produtos, mas não sabiam que eram derivados da mitologia. Isto nos fez pensar o quanto os produtos culturais se apropriam de coisas já existentes, as (re)significam, (re)estruturam com outras linguagens e (re)tornam no mercado para consumo. De certa forma, a mitologia se faz presente, permanece em nossa sociedade, porém em 
grande medida, distorcida dos seus valores originais ou, das diferentes formas que foram criadas, aparecendo, exclusivamente, sob um único modelo: o estereotipado.

A expressão gráfica das crianças é reveladora do tipo de aproximação que elas têm desse universo imagético: umas expressam aquilo que puderam apreender de uma história que não conheciam, mas que puderam visualizar durante a oficina, pois projetamos essas imagens; outras tentam reproduzir tal qual está na internet ou nos desenhos para colorir, mimetizando a forma conhecida. Sem querer discutir sobre o que é certo ou errado, precisamos estar atentos aos textos e imagens de produtos que as crianças estão tendo acesso e questionarmos: como as crianças estão consumindo esses produtos? De que maneira expressam o que têm consumido? Que educações estão sendo produzidas? Assim, consideramos que este estudo possa ser utilizado por professores e outros profissionais que trabalham com crianças, atentando-se ao que elas nos dizem/desenham/escrevem.

Esse interesse pelas manifestações infantis e juvenis são muito importantes para verificarmos a abordagem mais adequada em relação ao que iremos trabalhar, ao que vamos construir junto com nossos alunos. Pensamos que os desenhos podem nos ajudar, e muito, a pensar sobre a infância, a juventude e como essas pessoas têm consumido os produtos culturais que tem acesso. A falta de conhecimento sobre as Sereias, nos fez levar para a sala de aula uma imagem que correspondia ao que se tem produzido sobre Sereias no mundo contemporâneo: Sereia com cauda de peixe. Talvez, se tivéssemos mostrado várias formas que esses seres possuem, com cauda, com asas, como aves e não tivéssemos permitido que as crianças levassem os trabalhos para terminar em casa, poderíamos ter tido outra amostra. No entanto, desconheceríamos o que as tem influenciado no momento de fazer os seus desenhos, no caso, os desenhos para colorir.

Para finalizar, consideramos que a atenção ao território que habitamos, não só como pesquisadoras, mas também enquanto professoras ou responsáveis 
pelas crianças, é muito importante para ampliar os referenciais imagéticos com os quais elas entram em contato e que podem ampliar o repertório de imagens e possibilitar modos mais criativos e inventivos de expressão. Isso seria a consequência de uma educação visual mais rica e que amplia as possibilidades de leituras de mundo e, de fato, contribui na construção subjetividades.

\section{referências}

ALMEIDA, Milton José de. Imagens e sons: a nova cultura oral. São Paulo: Cortez, 1994.

PASSOS, Eduardo; KASTRUP, Virgínia; ESCÓSSIA, Liliana da (orgs.). Pistas do método da cartografia: pesquisa-intervenção e produção de subjetividade. Porto Alegre: Sulina, 2012.

COMMELIN, Pierre. Mitologia grega e romana. 2.ed. São Paulo: Martins Fontes, 1997.

DERDYK, Edith. Formas de pensar o desenho: desenvolvimento do grafismo infantil. 3. ed. São Paulo: Scipione, 2010.

GARZA, María Teresa de la. Filosofia e Literatura: uma relação estreita. In: KOHAN, Walter Omar; LEAL, Bernardina (orgs.). Filosofia para Crianças: em debates. 2. ed. Petrópolis: Vozes, 2000. (Coleção Filosofia na Escola, vol. IV)

HOMERO. Odisseia. Trad. Antônio Pinto de Carvalho. São Paulo: Nova Cultural, 2003. (Versão em prosa, rapsódia XII - Sereias).

IAVELBERG, Rosa. O desenho cultivado da criança: prática e formação de educadores. Porto Alegre, RS: Zouk, 2013.

IAVELBERG, Rosa. O desenho cultivado no percurso de criação do sujeito em arte. In: Trapézio: grupo de apoio à escolarização. Agosto de 2004. Disponível em: <http://www.trapezio.org.br/informativo/info4/artigo_1.htm>. Acesso em: 15 de dezembro de 2014.

KOHAN, Walter Omar. Sugestões para implementar a filosofia com crianças em escolas. In: KOHAN, Walter Omar; WAKSMAN, Vera (orgs.). Filosofia para Crianças: na prática escolar. 3. ed. Petrópolis: Vozes, 1998. (Coleção Filosofia na Escola, vol. II)

MÈREDIEU, Florence. O desenho infantil. 15 ed. São Paulo: Cultrix, 2006.

OVÍDIO. Metamorfoses. São Paulo: Madras, 2003.

VAZ, João. O Fado das Sereias. In: Marítimos: histórias e memórias do mar (Blogpost). $\quad 2012.2$ Dgo. Disponível <http:// maritimo.blogspot.com.br/2012/08/o-fado-das-Sereias.html>. Acesso em: 20 de março de 2013. 